\title{
Effect of E-Performance Appraisal on Employee Performance in the Presidential Amnesty Programme Office, Abuja
}

\author{
Chioma Michael-Ofre a , Michael Isaac Opusunju b, \\ E-mail: cmichaelofre@gmail.com; Phone №.: +2348068775614 \\ ${ }^{a}$ Department of Business Administration, Bingham University, Karu, Nasarawa State \\ ${ }^{\mathrm{b}}$ Department of Business Administration, Nile University of Nigeria, Abuja.
}

\begin{abstract}
The study investigated the effect of e-Performance Appraisal on Employee Performance in the Presidential Amnesty Programme Office, Abuja, Nigeria. The objective of the study is to specifically assess the effect of the proxies of eperformance appraisal viz. goal setting, e-performance review and feedback on employee performance. The study made use of a survey research design; where primary data were collected from a census sample of 122 management and operational level employees in the Presidential Amnesty Programme Office in Abuja. All the questionnaire issued was completed and returned representing a 100\% response rate. The questionnaires contained closed-ended questions that were rated on a Likert-5-point Scale of "Strongly Agree, Agree, Undecided, Strongly Disagree and Disagree." The data was then analysed with the Multiple Linear Regression. Arising from the result, the model was significant at 0.000 and the null hypothesis was rejected. It was concluded that the employee performance Presidential Amnesty Programme Office in Abuja is affected by e-Performance Appraisal, however, of the proxies tested, e-Performance Review is insignificant, while Goal Setting and Feedback are significant. The study recommends that organisations that seek to increase their employee performance should shift from the traditional performance appraisal system to the ePerformance Appraisal system. This is because e-Performance Appraisal has a positive effect on employee performance.
\end{abstract}

Key Words: E-Performance Appraisal, Goal Setting, e-Performance Review, Feedback, Employee Performance.

\section{Introduction}

Performance appraisals encompasses the methodical assessments of the performance of employees in the bid to understand their abilities for further growth and development (Murphy et al, 2019). Over the years, it is believed that an organization is as good as its employees-where employees are properly appraised, their performance can be developed which could, in turn, grow the organisation. More so, performance appraisal serves as a great motivational tool that provides rewards and recognitions for high performing employees, identification of gaps and Performance Improvement Plan (PIP) or Personal Development Plan (PDP) to support employees that need improvement (AfDB Group, 2017). In retrospect, Performance Appraisal tends to improve work performance, communication of expectations, determining employee potential and aiding employee counselling (Aggarwal \& Thakur, 2013). According to Moraa and Datche (2019), performance appraisal has been widely adopted by both the public and private sectors and $74 \%$ to $89 \%$ of firms now have a formal Performance Appraisal system. In some organizations, a single method is used while others use a combination of methods involving electronic and manual methods to achieve their desired objective.

Whilst manual appraisals may involve paperwork, electronic performance appraisal (e-performance appraisal), is an employee review created and delivered electronically (Milano, 2021). It is a competency-based system that measures people not only on goal attainment but on the very competencies that are required for their role. It is impersonal, more objective, saves time, provides better data, and leaves a trail. In all of these, e-Performance Appraisal involves goal setting, performance review and feedback. Meanwhile, manual performance appraisal encompasses laborious intense work followed by consensus meetings, one-on-one discussions that would end up stacking a pile of papers for the appraiser or human resources (HR) manager.

With the advent of technology, most organizations have migrated from manual performance appraisals to eperformance appraisals for ease of administration, speed, efficiency, reliability and overall cost-effectiveness (Ullah et al, 2021). The Presidential Amnesty Programme, Abuja is one of those organizations that have adopted the electronic performance appraisal system. Despite the use of e-performance appraisal for evaluation, recognition and reward of employees, it has been observed that it is not delivering the expected benefits-employees' performance in terms of 
attitude to work, job satisfaction and productivity remained the same. Hence, the need for research. Extant empirical literature such as Obisi (2011), Aggarwal and Thakur (2013), Moraa and Datche (2019), Marr (2020) amongst others, have examined the effect of performance appraisal on employees' performance, however, none of these studies considered e-performance appraisals. Meanwhile, they equally did not consider employee work attitude, employee productivity and job satisfaction as measures of employee performance which presented an empirical gap for the study. Furthermore, none of these studies used the Presidential Amnesty Programme office in Abuja to study the variables.

The main objective of the study is to examine the effect of e-performance on employees' performance in the Presidential Amnesty Programme Office in Abuja. Other specific objectives of the study are to examine the effect of goal setting, performance review and employees' e-appraisal feedback on employees' performance in the Presidential Amnesty Programme Office in Abuja. In line with the aforementioned objectives, the study hypothesized as follows:

$\mathrm{H}_{01}$ : There is no significant effect of goal setting on employees' performance in the Presidential Amnesty Programme Office in Abuja.

$\mathrm{H}_{02}$ : There is no significant effect of e-performance review on employees' performance in the Presidential Amnesty Programme Office in Abuja.

$\mathrm{H}_{03}$ : There is no significant effect of e-appraisal feedback on employees' performance in the Presidential Amnesty Office in Abuja.

\section{Literature Review}

\subsection{Conceptual Framework: E-Performance Appraisal and Employee Performance}

E-Performance Appraisal is an automated (electronic) performance appraisal system that enables employees to write self-appraisals, allows managers to write performance appraisals, get input from others such as committee members, as well as, set goals (Meral, 2020). Rondeau (2018), averred that applying electronic Human Resources Management (eHRM) to performance management has enabled organizations to provide feedback on a more frequent basis, to enhance employees' participation and accountability, to involve peers in the feedback process, and to enhance the social outcomes of performance feedback. Real-time goal setting is often integrated into e-HRM tools with a clear linkage between individual and organizational.

Aggarwal and Thakur (2013), averred that Performance Appraisal is a critical component of the staffing function of the HR manager. The overall objective of e-Performance Appraisal is to improve the efficiency of an enterprise by mobilizing the best possible efforts from individuals employed in it. Obisi (2011), added that a typical performance appraisal system is broadly divided into three based on the feedback mechanism used. This could be confidential, open or semi-open/semisecret. Meanwhile, a performance appraisal system yields optimum employee performance when the employee feels that the appraisal process is a regular, honest, fair and constructive two-way conversation (Marr, 2020).

\subsubsection{Goal Setting}

Organizations are founded with goals and objectives that needed to be achieved. As such, the performance of each employee is measured against the organizational goal, therefore employees must know what is expected of them and set their individual goals to align with the organization goal. According to Robbins (2021), Goal setting is that the process of identifying something one wishes to accomplish and establishing measurable objectives and timeframes to assist one in achieving it (Robbins, 2021). It involves the event of an action plan designed to motivate and guide an individual or group toward a goal.

Goals direct effort and focus toward all activities that are associated with achieving them. As such, difficult goals result in more effort than easy goals, so it may be said that goals, in general, have energizing function. According to Bagobiri, Gambo and Kassah (2020), the mix of goal difficulty and also the extent of the person's commitment to achieving the goal regulates the extent of effort expended. As such, employees with specific quantitative goals like an outlined level of performance or a given completion deadline for a task would most likely perform better than employees without set goals - irrespective of the goal difficulty.

\subsubsection{E-Performance Review}

For performance to be rewarded, it must be reviewed from time to time, even if the data is collected electronically. Performance review encompasses constructing accurate and objective performance observations on the premise of outcomes and expectations which are in an employee's performance plan and are duly reflected within the performance appraisal to develop the performance of the employee (Moraa \& Datche, 2019). Using electronic means, the e-performance 
review provides a platform to equally evaluate an employee's work performance, identify strengths and weaknesses, offer feedback, and set goals for future performance (BambooHR, 2021; Pernicek, 2021). Real performance is re-evaluated after a particular period to assess whether the objectives are being achieved.

\subsubsection{Feedback}

After every performance review, it is expected that information on the rater's evaluative judgement of an employee's performance is communicated to the employee. Moraa and Datche (2019), define feedback as the machinery put in place by an organisation to communicate information of employee's past performance based on the appraisal to the employee. Whilst in e-appraisal feedback are given faster, Leonard (2018), averred that feedback is critical to helping employees quickly understand expectations, make adjustments and acquire the coaching necessary to boost their performance and succeed. It is, therefore, an ongoing communication process where information is exchanged between a manager and a team member to understand where things are going right or wrong and make adjustments where necessary. When done consistently and well, the performance feedback process ends up in better performance on the individual and organizational levels, higher satisfaction and morale among staff, retention of strong performers and a good means for correcting poor performance (Einstein, 2021).

\subsubsection{Employees Performance}

It is believed that employees' performance is relatively unique, stable, predictable, determinable and controllable (Idowu, 2017). This does not mean that employee performance does not result in sundry indicators with which to measure. Nevertheless, employee performance is originally what an employee does or does not do. According to Murphy et al (2011), the performance of employees could include the quantity of output, quality of output, timeliness of output, presence at work, cooperativeness. For this research, employees' commitment, motivation, satisfaction, attitude and overall output are considered.

Employee commitment reflects the involvement and psychological attachment that an employee has towards an organization and work which is assigned to him or her. According to Mugizi, Bakkabulindi, and Bisaso (2015), employee commitment is a bond between the employee and the organization - where the employee wants to continue serving the organization and to help it achieve its objectives. Meyer, Stanley and Parfyonova (2012), described commitment as an internal psychological force that makes an individual stick to a course of action that is of relevance to a particular goal. As such, employee commitment could be described as a working condition that if achieved can sustain their effectiveness and contribute to high organisational performance.

Job satisfaction is an employee's emotional response to his or her current job condition, whereas motivation represents the driving force to pursue and satisfy one's needs. According to Alshallah (2004), many employers have started to recognize that a "happier" employee is more motivated and tend to perform better at the workplace. According to Ali (2016), job satisfaction is a pleasurable or positive emotional state resulting from the appraisal of one's job or job experiences. Aziri (2011), equally asserts that job satisfaction represents a combination of positive or negative feelings that workers have towards their work and Thiagaraj and Thangaswamy (2017), opine that it is an individual's complex attitude towards his or her job. Meanwhile, motivation "energizes behaviour, gives direction to behaviour and underscores the tendency to persist" (Islam \& Ismail, 2008). Whilst job satisfaction, thus, has to do with an individual's perception and evaluation of their job, motivation continues to be an important aspect by leading function in influence on an employee to work towards organisational goals. The elements of job satisfaction and motivation are related to pay, promotion, benefits, work nature, supervision and relationship with colleagues.

Productivity is defined as the efficient and effective use of resources with minimum waste and effort to achieve an outcome. As such, employees' attitude is closely related to their productive output. According to Katz (2018), employee attitude describes the actions of employees towards their objectives and goals. He proposed that an attitude is the predisposition of the individual to assess a particular object favourably or unfavourably. Crano and Prislin (2016) averred that attitudes are the evaluative judgments that integrate and synchronize cognitive/affective reactions. An attitude could be seen as a mental and neural state of readiness, organized through adequate experience, exerting a directive or dynamic influence upon the employees' response to all objects and situations with which they are interlinked (Thezasvini, Karthikeyan \& Manikandan, 2018).

\subsection{Theoretical Framework: Goal Setting Motivation Theory}

Locke and Latham (1979), brought about the goal-setting motivation technique which they considered as not only more effective than other methods but also can be treated as a support for them. In their approach, a goal is defined as an 
object or aim of an action that is attained within a specific limit of time. One of their core findings is that the highest level of performance and effort is produced when the difficulty level of attaining goals is also very high. The only limit is the ability of the person who tries to attain a goal. The authors found that people perform better if a specific difficult goal is set than if they are asked to perform as well as they can (Locke \& Latham, 2002). Their work also showed that performance does not differ among employees regardless of whether goals are assigned to people or if people participate in choosing their own goals. This was explained by the fact that usually the superior that assigns the goal is treated as an authority. Furthermore, the act of assigning a goal means that the superior believes that the subordinate can fulfil that goal. As a result, people became motivated to prove their competencies.

However, this study relies on the above theory because it provides a strong link between goal setting, which is a subset of performance appraisal and the performance of employees. The theory also asserts that goal setting leads to employees' commitment and job satisfaction.

\subsection{Empirical Studies}

Onyije (2015), investigated the effect of the appraisal system in Niger Delta University on employee productivity. The methodology employed was a survey study design. The population of the study comprises about 3478 Academic and nonacademic staff. The researcher sampled 3\% of the total population using stratified random sampling. The instrument used was a self-developed questionnaire distributed to 104 respondents of which 102 were retrieved. The correlation coefficient was used to test the hypothesis. The study revealed that there was a significant relationship between performance appraisal and employee productivity and that an effective appraisal system could boost the morale of workers especially when they are rated adequately. The findings also revealed that performance criteria also affect the relationship between performance appraisal and employee productivity. Whilst, Onyije (2015), was able to test the hypotheses of her study, she failed to show whether her model was fit.

Kephas (2016), determined the effect of performance appraisal on employee productivity in the Ministry of Agriculture Homa Bay County, Kenya. The study targeted 256 employees in the Ministry of Agriculture, Homa Bay County out of which a sample size of 156 respondents were randomly determined using Yamane (1967) formula. A calculated coefficient of at least 0.70 indicated that the instrument was reliable. The researcher calculated a reliability coefficient of 0.87 . Findings of the study revealed that performance appraisal criteria, feedback and reward were all adopted to great extents by the Ministry of Agriculture, Homa Bay County as shown by their weighted mean of 3.65, 3.83 and 4.15 respectively. The regression results revealed that when independent variables (appraisal criteria, feedback and reward) are controlled for or held constant, there is a probability that employee performance would be affected positively by a coefficient of ( $\mathrm{r}=$ 1.217), this effect being significant at $(\mathrm{p}=.0342)$. In his model, Kephas (2016), depicted that working environment, organization culture and management style were intervening variables, however, he failed to test this in his study. If the intervening variables were taken cognizance of, the result would have been different which would provide a better explanation of the study variables.

Moraa and Datche (2019), studied the effect of performance appraisal on employee performance using the National Health Insurance Fund (NHIF) of Kenya as a case study. The specific objective was to establish the effect of goal setting, performance planning, performance review and feedback on employee performance. The target population of the study comprised 306 employees working in NHIF Head Office in Nairobi County. The data were collected using structured questionnaires based on the research hypotheses. Furthermore, the data were analysed with the aid of Statistical Package for Social Science (SPSS) version 23. The study established that there is a positive relationship between performance review and employee performance. The goal-setting had a significant influence on employee performance. The coefficients also showed a positive relationship between all the variables and employee performance. Whilst Moraa and Datche (2019), did a good analysis for their data, they did not examine their questionnaire for face cogency or test the reliability of their research instrument. As such, the structure of their research instrument may be misleading to their respondents.

Ugoani (2020), examined performance appraisal and its effect on employees' productivity in charitable organizations in Nigeria. The judgmental sampling method was used to select the sample of the study. The sample size of 109 was determined through the sample ratio concept. Using the exploratory research design and 109 participants the result of the study indicates a strong positive correlation between performance appraisal and employee productivity. Whilst the correlation coefficient is good for knowing whether the computed value of $r$ is significant or not, it does not indicate whether there exists any cause-and-effect relationship of the variable. Hence, Ugoani (2020), failed to consider evaluating whether or not a linear relationship exists between performance appraisal and employees' productivity. 
Rahahleh, Alabaddi and Moflih (2019), investigated the effect of performance appraisal on employees' work performance of banks in the South of Jordan. This specifically aimed at investigating some major elements of performance appraisal viz. establishing performance standards, establishing communication standards, measuring actual performance with established standards, discussing the appraisal with employees and giving feedback. The required data for the study was primarily collected through a closed-ended structured questionnaire. A total of 260 questionnaires were distributed to the entire employee population of the banks in the South of Jordan, of which all were completed and returned; representing a 100\% response rate. The 260 returned questionnaires were then analyzed using SmartPLS software; especially used for Structural Equation Modeling, path analysis, and confirmatory factor analysis. The results of the study showed that performance appraisal has a mainly positive effect on employee performance in the banking sector of the South of Jordan. Their correlation analysis showed that there was a positive and some negative association between performance appraisal and employee performance. Like Ugoani (2020), Rahahleh et al (2019), equally failed to consider evaluating whether or not a linear relationship exists among their study variables.

\section{Methodology}

The study adopted the survey research design of which relies on responses gotten from primary data. The population of the study comprised all the 122 management and operational level employees in the Presidential Amnesty Programme Office in Abuja and this was also used as the census sample. The study adopted a primary approach using a self-structured questionnaire for data collection.

All the 122 questionnaires issued was completed and returned representing a 100\% response rate. The questionnaires contained closed-ended questions because it was an easier and quicker way for respondents to answer. The questionnaires were rated on a Likert-5-point Scale of "Strongly Agree, Agree, Undecided, Strongly Disagree and Disagree." The choice of the questionnaire is one of the means of gathering data that is borne out of the fact that it is cheap and does not require as much effort from the questioner as verbal or telephone surveys. The questionnaire used in this study was assessed and examined for its face cogency. Meanwhile, the face cogency was reached through examining carefully the layout and structure of the questionnaire. The administered questionnaires were subjected to test so as to ensure its reliability. The method used for testing for the internal consistency was the Cronbach's Alpha, which is computed with the model:

$$
\alpha=\frac{N r}{1+r(N-1)}
$$

Where:

$\alpha=$ Cronbach Alpha; $\mathrm{N}=$ the number of items in the scale; $r=$ the mean inter-item correlation.

Table 3.1.: Result of Reliability Test

\begin{tabular}{lll} 
& $\begin{array}{l}\text { Cronbach's Alpha } \\
\text { Co-efficient }\end{array}$ & Questions \\
\hline Effect of Goal Setting (GS) & 0.71 & 0.6016 \\
\hline Effect of e-Performance Review (PR) & 0.78 & 0.6360 \\
\hline Feedback on Employees (FB) & 0.82 & 0.7032 \\
\hline Employees performance (EP) & 0.76 & 0.7048 \\
\hline
\end{tabular}

Source: Researcher's Computation, 2021

In the case of this study, the levels of alpha values are above the 0.7 which were considered as reliable—Cronbach's $\alpha>0.70$ (Field, 2009).

The primary data were analysed using the SPSS version 25. The descriptive statistics were the mean and standard deviation while the inferential statistics included analysis Multiple Linear Regression to determine the effect of the independent variable on the dependent variable. The statistical model used was:

$\mathrm{Y}=\mathrm{a}+\mathrm{bx}+\mu$

This is specified thus as:

$\mathrm{EP}=\alpha+\beta_{1} \mathrm{GS}+\beta_{2} \mathrm{PR}+\beta_{3} \mathrm{FB}+\mu$

Where:

$\mathrm{EP}=$ Employee Performance; $\alpha=$ intercept or constant; $\beta=$ Coefficient; GS = Goal Setting; PR = e-Performance Review; $\mathrm{FB}=$ Feedback; $\mu=$ Error Term 


\section{Data Presentation and Result}

\subsection{Descriptive Statistics}

To establish the effect of e-performance appraisal on employee performance, a Likert scale data was collected rating the extent of the agreement on the scale from 1 to 5 ; where 1 is the strongly disagree and 5 is the strongly agree indicator. The results from the collected responses were analysed based on means and their standard deviations to show the variability of the individual responses from the overall mean of the responses per each variable of the study.

Table 4.1.: Effect of Goal Setting (GS)

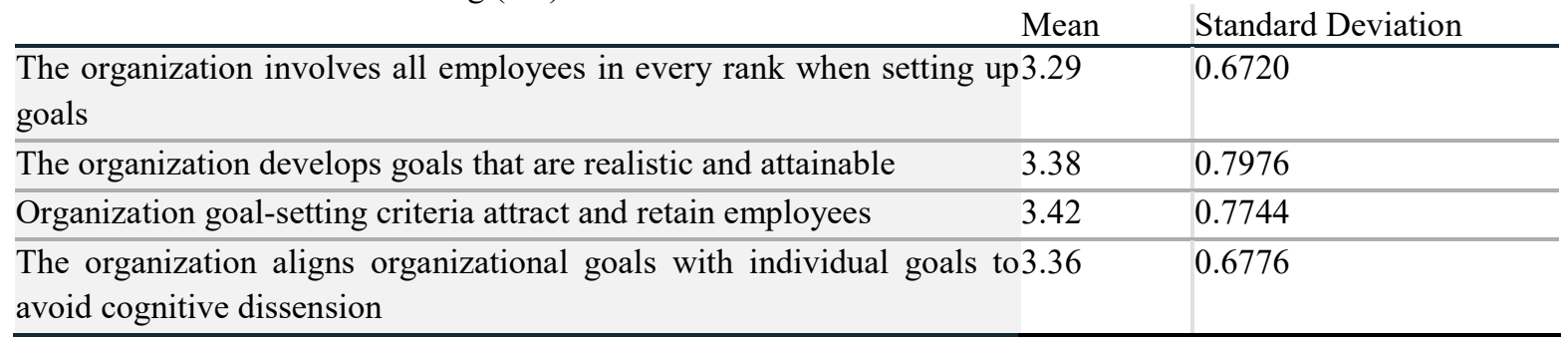

The result in Table 4.1. show the mean responses on goal setting in the Presidential Amnesty Programme Office, Abuja. From table 4.1, the respondents slightly agreed (mean $=3.29$; Standard Deviation $=0.6720)$ that the organization involves all employees in every rank when setting up goals. Likewise, the respondents slightly agreed (mean $=3.38$; Standard Deviation $=0.7976)$ that the organizational goals are realistic and attainable. Also, the respondents slightly agreed $($ mean $=3.42$; Standard Deviation $=0.7744)$ that the goal-setting criteria of the organisation attract and retains employees. Finally, the respondents equally slightly agreed (mean $=3.36$; Standard Deviation $=0.6776$ ) that the organization aligns organizational goals with individual goals to avoid cognitive dissension.

Table 4.2.: Effect of e-Performance Review (PR)

\begin{tabular}{ll}
\hline $\begin{array}{l}\text { Progress reviews are conducted to compare the predetermined standards3.73 } \\
\text { of employees }\end{array}$ & Standard Deviation \\
$\begin{array}{l}\text { The organization e-performance review technique is effective and4.10 } \\
\text { objective }\end{array}$ & 0.8074 \\
\hline $\begin{array}{l}\text { The organization sets performance standards that are fair and achievable4.08 } \\
\text { My performance is reviewed in annual intervals based on performance4.04 }\end{array}$ & 0.6422 \\
\hline \begin{tabular}{l} 
indicators \\
\hline
\end{tabular}
\end{tabular}

The results in Table 4.2. show the mean responses on e-performance review in the Presidential Amnesty Programme Office, Abuja. From table 4.2, the respondents slightly agreed (mean $=3.73$; Standard Deviation $=0.8074)$ that progress reviews are conducted to compare the predetermined standards of employees. However, the respondents agreed (mean $=$ 4.10; Standard Deviation $=0.7584)$ that the organization e-performance review technique is effective and objective. Likewise, the respondents agreed (mean $=4.08$; Standard Deviation $=0.6422)$ that the organization sets performance standards that are fair and achievable. Finally, the respondents equally agreed (mean $=4.04$; Standard Deviation $=0.6509)$ that their performance is reviewed in annual intervals based on performance indicators.

Table 4.3.: Feedback on employees (FB)

\begin{tabular}{ll}
\hline \multicolumn{1}{c}{ Mean } & Standard Deviation \\
\hline $\begin{array}{l}\text { The e-performance evaluation system provides effective feedback } \\
\text { There are discussions between my supervisor and myself during an e-3.22 } \\
\text { performance assessment }\end{array}$ & 0.6016 \\
\hline $\begin{array}{l}\text { The organization provides e-performance appraisal feedback annually } 3.34 \\
\begin{array}{l}\text { The organization performance feedback is communicated through3.41 } \\
\text { electronic mode }\end{array}\end{array}$ & 0.7032 \\
\hline
\end{tabular}


The results in Table 4.3. show the mean responses on feedback on employees in the Presidential Amnesty Programme Office, Abuja. From table 4.3, the respondents slightly agreed (mean $=3.25$; Standard Deviation $=0.6016$ ) that the organization's performance evaluation system provides effective feedback. Likewise, the respondents slightly agreed $($ mean $=3.22$; Standard Deviation $=0.6360)$ that there are discussions between their supervisors and themselves during eperformance assessments. Also, the respondents slightly agreed (mean $=3.34$; Standard Deviation $=0.7072$ ) that the organization provides e-performance appraisal feedback annually. Finally, the respondents equally slightly agreed (mean $=3.41$; Standard Deviation $=0.7048$ ) that the organization's performance feedback is communicated through electronic mode.

Table 4.4.: Employees performance (EP)

\begin{tabular}{ll}
\hline $\begin{array}{l}\text { The organizational goals have been attained as a result of the e-3.47 } \\
\text { performance appraisal }\end{array}$ & Standard Deviation \\
\hline $\begin{array}{l}\text { The e-performance appraisal introduction has led to increased employee } 3.50 \\
\text { motivation and job satisfaction }\end{array}$ & 0.6728 \\
$\begin{array}{l}\text { E-performance appraisal has enhanced organizational productivity of the 3.51 } \\
\text { labour force }\end{array}$ & 0.7248 \\
\hline
\end{tabular}

The results in Table 4.4. show the mean responses on employee performance in the Presidential Amnesty Programme Office, Abuja. From table 4.4, the respondents slightly agreed (mean $=3.47$; Standard Deviation $=0.6728$ ) that the organizational goals have been attained as a result of the e-performance appraisal. Likewise, the respondents slightly agreed $($ mean $=3.50$; Standard Deviation $=0.6856)$ that e-performance appraisal introduction has led to increased employee motivation and job satisfaction. Finally, the respondents slightly agreed $($ mean $=3.51$; Standard Deviation $=$ 0.7248 ) that e-performance appraisal has enhanced the organizational productivity of the labour force.

\subsection{Multiple Linear Regression Analysis}

The model and hypotheses were tested at a 0.05 significance level. Table 4.5 . shows a model summary that is used to measure how well the regression model fits the data.

Table 4.5.: Model Summary

\section{Model Summary}

\begin{tabular}{lllll} 
Model & $\mathrm{R}$ & R Square & $\begin{array}{l}\text { Adjusted } \\
\text { Square }\end{array}$ & $\begin{array}{c}\text { RStandard Error of } \\
\text { the Estimate }\end{array}$ \\
\hline 1 & $0.663^{\mathrm{a}}$ & 0.439 & 0.425 & 0.50526 \\
\hline
\end{tabular}

a. Predictors: (Constant), FB, PR, GS

Source: Researcher's Computation

As shown in Table 4.5, the Multiple $\mathrm{R}$ of 0.663 , indicates a strong linear effect the independent variable and the dependent variable. The model also has an R Square of 0.439 meaning that the independent variable explains $43.9 \%$ of the variability of the dependent variable - it further shows that other proxies that may affect employee performance not tested in the study amount to about $56.1 \%$. The Adjusted R Square was 0.425 , an indication that there was a variation of $42.5 \%$ on the employee productivity due to changes in the e-performance appraisals. The Standard Error of the Estimate shows that the observed values fall an average of 0.50526 units from the regression line.

Table 4.6.: Analysis of Variance (ANOVA) ANOVA ${ }^{\mathrm{a}}$

\begin{tabular}{lll|llll} 
Model & & Sum of Squares & df & Mean Square & F & Sig. \\
\hline 1 & Regression & 23.586 & 3 & 7.862 & 30.796 & $0.000^{\mathrm{b}}$ \\
\cline { 2 - 7 } & Residual & 30.124 & 118 & 0.255 & & \\
\cline { 2 - 7 } & Total & 53.710 & 121 & & & \\
\hline
\end{tabular}

a. Dependent Variable: EP

b. Predictors: (Constant), FB, PR, GS

Source: Researcher's Computation

From the ANOVA table (Table 4.6), the processed data had a significance level of 0.000 , which shows that the data is ideal for concluding the population parameters as the value of significance ( $p$-value) is less than 0.05 . More so, the 
calculated value was greater than the critical value $(30.796>2.70)$ — an indication that there was a significant effect of eperformance appraisal on employee performance.

Table 7: Coefficient of Determination Coefficients ${ }^{\mathbf{a}}$

\begin{tabular}{|c|c|c|c|c|c|c|}
\hline \multirow{2}{*}{\multicolumn{2}{|c|}{ Model }} & \multicolumn{2}{|c|}{$\begin{array}{l}\text { Unstandardized } \\
\text { Coefficients }\end{array}$} & \multirow{2}{*}{$\begin{array}{l}\text { Standardized } \\
\text { Coefficients } \\
\text { Beta } \\
\end{array}$} & \multirow[b]{2}{*}{$\mathrm{t}$} & \multirow[b]{2}{*}{ Sig. } \\
\hline & & $\mathrm{B}$ & Std. Error & & & \\
\hline \multirow[t]{4}{*}{1} & (Constant) & 15.354 & 0.322 & & 47.733 & 0.000 \\
\hline & Goal Setting (GS) & 0.716 & 0.216 & 0.416 & 3.313 & 0.001 \\
\hline & $\begin{array}{l}\text { Performance Revieu } \\
\text { (PR) }\end{array}$ & v0.437 & 0.251 & 0.226 & 1.742 & 0.084 \\
\hline & Feedback (FB) & 0.611 & 0.076 & 0.590 & 8.014 & 0.000 \\
\hline
\end{tabular}

a. Dependent Variable: Employee Performance (EP)

Source: Researcher's Computation

From Table 4.7 above, and in line with Equation (3.2), the statistical model could be represented as: $15.354=\alpha+0.716 \mathrm{GS}+0.437 \mathrm{PR}+0.611 \mathrm{FB}+\mu$

Following Table 4.7 above, it was revealed that holding the e-Performance Appraisal to a constant zero, Employee Performance (EP) would stand at 15.354. Nevertheless, the variables are as follows: A unit increase in Goal Setting (GS) would lead to an increase in EP by a factor of 0.716 ; with GS being significant at 0.001 . Also, a unit increase in Performance Review (PR) may lead to an increase in EP by a factor of 0.437 , however, the $t$-test revealed that PR is not significant; being that the significance of PR (0.084) is above the 0.05 study significance level. Furthermore, a unit increase in Feedback (FB) would significantly lead to an increase in the EP by a factor of 0.611 ; with FB being significant at 0.000 . This depicts that Goal Setting has the leading effect on Employee Performance, followed by Feedback.

Table 4.8.: Summary of Hypotheses

Hypothesis Statement

\begin{tabular}{c|c} 
Model & Result \\
\hline $\mathrm{EP}=\alpha+\beta_{1} \mathrm{GS}+\mu$ & $\mathrm{p}<0.05$ Rejected \\
\hline $\mathrm{EP}=\alpha+\beta_{2} \mathrm{PR}+\mu$ & $\mathrm{p}>0.05$ Accepted \\
\hline $\mathrm{EP}=\alpha+\beta_{3} \mathrm{FB}+\mu$ & $\mathrm{p}<0.05$ Rejected
\end{tabular}
employees' performance in the Presidential Amnesty Office in Abuja

Source: Researcher's Result

From Table 4.8 above, the null hypothesis for hypotheses 1 and 3 is rejected in favour of the alternate hypotheses. Whereas, the hull hypothesis for hypothesis 2 is accepted.

\section{Conclusion and Recommendations}

\subsection{Conclusion}

It is very vital to ensure the quality of performance appraisal reports to enable managers to make timely and correct decisions. From this study, it is evident that the integration of technology in HR management produces better outcomesoverall, the employee performance of the Presidential Amnesty Programme Office in Abuja is affected by e-Performance Appraisal. Although in testing the proxies for e-Performance Appraisal in the study, it was found out that e-Performance Review is insignificant, while Goal Setting and Feedback are significant. This result is similar to the position of Ullah et al (2021), who averred that it is imperative for organizations to change their traditional performance management system to an electronic-based one to gain accuracy in their evaluations.

Regarding the issue of the Presidential Amnesty Programme Office being perceived as not affected by e-performance appraisals, it could be as a result of the Office focusing on e-Performance Reviews which is not yielding a significant 
effect. Nevertheless, the increase in goal setting and feedback would significantly increase Employee Performance in terms of increased employee motivation, job satisfaction and productivity.

\subsection{Recommendations}

Since goals setting has the leading positive effect on employee performance, the study recommends that organizations should involve all their employees in every rank when setting up goals, as this gives employees a sense of ownership in achieving their goals. Also, organisations should ensure to set up goals that are realistic and attainable; they should equally align organizational goals with individual goals to avoid cognitive dissension.

Also, because feedback positively affects employee performance, the study recommends that organizations' eperformance evaluation system should provide effective feedback where discussion can take place between an employee and his/her supervisor. Furthermore, organizations should provide e-performance appraisal feedback at least annually.

Finally, the study recommends that organisations that seek to increase their employee performance should shift from the traditional performance appraisal system to the e-Performance Appraisal system. This is because e-Performance Appraisal has a positive effect on employee performance. 


\section{References}

AfDB Group. (2017). The African Development Bank's human resource management policy and strategic directions: A formative evaluation (Rep.). African Development Bank Group. Retrieved October 21, 2021, from https://www.oecd.org/derec/afdb/afdb-idev-Human-Resources.pdf.

Aggarwal, A., \& Thakur, G. (2013). Techniques of performance appraisal - A review. International Journal of Engineering and Advanced Technology (IJEAT), 2(3), 617-621.

Ali, W. (2016). Understanding the concept of job satisfaction, measurements, theories and its significance in the recent organizational environment: A theoretical framework. Archives of business research, 4(1). doi:10.14738/abr.41.1735

Alshallah S. (2004). Job satisfaction and motivation: how do we inspire employees?. Radiology management, 26(2), 47-51.

Aziri, B. (2011). Job satisfaction: A literature review. Management Research and Practice, 3(4), 77-86.

Bagobiri, E., Gambo, N., \& Kassah, V. (2020). Readings in management/organisational theory \& organisational behaviour. Kaduna: Authors.

BambooHR. (2021). An HR glossary for HR terms. Retrieved November 24, 2021, from https:/www.bamboohr.com/hr-glossary/performancereview/\#: :text=A\%20performance\%20review\%20is\%20a,performance\%20appraisals $\% 20$ or\%20performance $\% 20$ evaluations.

Einstein. (2021). Performance Feedback Program. Retrieved November 28, 2021, from https://einsteinmed.edu/administration/humanresources/performance-feedback.html

Field, A. (2009). Discovering statistics using SPSS (3rd ed.). London: Sage.

HRwale. (2020, October 5). Performance management: Performance appraisal methods. Retrieved November 19, 2020, from https://corehr.wordpress.com/performance-management/performance-appraisal-methods/

Idowu, A. (2017). Effectiveness of performance appraisal system and its effect on employee motivation. Nile Journal of Business and Economics, 3(5), 15-39. doi:10.20321/nilejbe.v3i5.88

Islam, R., \& Ismail, A. Z. H. (2008). Employee motivation: A Malaysian perspective. International Journal of Commerce and Management, 18(4), 344362 .

Kephas, O. B. (2016). Effect of performance appraisal on employee productivity in the Ministry of Agriculture Homa Bay County, Kenya. International Journal of Advanced Research, 4(3), 488-495.

Leonard, K. (2018). What is performance feedback. Retrieved November 28, 2021, from https://smallbusiness.chron.com/performance-feedback1882.html

Locke, E. A., \& Latham, G. P. (2002). Building a practically useful theory of goal setting and task motivation: A 35 -year odyssey. American Psychologist, 57(9), 705-717. doi:10.1037/0003-066X.57.9.705

Marr, B. (2020). Key tools and techniques for performance management. Retrieved November 19, 2020, from Bernard Marr \& Co.: https://www.bernardmarr.com/default.asp?contentID=772

Meral, Y. (2020). Tools and techniques for implementing international e-trading tactics for competitive advantage. IGI Global. doi:10.4018/978-1-7998$0035-4$

Milano, S. (2021). Advantages \& disadvantages of electronic performance appraisals. Retrieved November 22, 2021, from https://work.chron.com/advantages-disadvantages-electronic-performance-appraisals-20351.html

Moraa, A., \& Datche, E. (2019). Effect of performance appraisal on employee performance: A case study of National Health Insurance Fund. The Strategic Journal of Business and Change Management, 6(2), 424-442.

Mugizi, W., Bakkabulindi, F., \& Bisaso, R. (2015). Framework for the study of employee commitment. Makerere Journal of Higher Education, 2(7), 15-47. doi:10.4314/majohe.v7i2.2

Murphy, K. R., Cleveland, J., \& Hanscom, M. E. (2019). Performance appraisal and management. Thousand Oaks, California: SAGE Publications.

Obisi, C. (2011). Employee performance appraisal and its implication. Australian Journal of Business and Management Research, 1(9), 92-97.

Onyije, O. C. (2015). Effect of performance appraisal on employee productivity in a Nigerian university. Journal of Economics \& Business Research, $12(2), 65-81$.

Pernicek, T. (2021). What is a Performance Review [Definition]: Types of Performance Reviews. Retrieved November 24, 2021, from https://www.quantumworkplace.com/future-of-work/what-is-a-performance-review

Rahahleh, A., Alabaddi, Z., \& Moflih, M. (2019). The impact of performance appraisal on employee performance in banks operating in the south of Jordan. International Journal of Human Resource Studies, 9(4). doi:10.5296/ijhrs.v9i4.15317

Robbins, T. (2021). How can i learn to set and achieve goals. Retrieved November 24, 2021, from https://www.tonyrobbins.com/ask-tony/can-createcompelling-future/

Rondeau, K. V. (2018). E-Performance and reward management. In e-HRM: Digital Approaches, Directions \& Applications (Chapter 12). Milton Park, UK: Routledge.

Thezasvini, K. J., Karthikeyan, A. J., \& Manikandan, R. J. (2018). A study on employees' attitude towards the organization and job satisfaction of employees in textile industry, Tiruppur district, Tamilnadu. Journal of Management and Science, 8(3), 230-242. doi:10.26524/jms.2018.23

Thiagaraj, D., \& Thangaswamy, A. (2017). Theoretical concept of job satisfaction - A Study. International Journal of Research - Granthaalayah, 5(6). doi:10.29121/granthaalayah.v5.i6.2017.2057

Ugoani, J. N. (2020). Performance appraisal and its effect on employees' productivity in charitable organizations. Business, Management and Economics Research, 6(12), 166-175. doi:10.32861/bmer.612.166.175

Ullah, Z., Ahmad, N., Scholz, M., Ahmed, B., Ahmad, I., \& Usman, M. (2021). Perceived accuracy of electronic performance appraisal systems: The case of a non-for-profit organization from an emerging economy. Sustainability, 13 